\title{
Study of ternary metal oxides as supercapacitor electrodes
}

\author{
B. Bhujun, S. Anandan \& M. T. T. Tan \\ University of Nottingham Malaysia Campus, Malaysia
}

\begin{abstract}
Supercapacitors are energy storage devices that make use of ion adsorption (electrochemical double layer capacitors) or fast surface redox reactions (pseudocapacitors). They complement batteries in electrical energy storage. Recent advances in charge storage mechanisms and the development of advanced nanostructured materials has yielded notable improvement in the performance of supercapacitors. The structural and electrochemical properties of the mixed metallic oxides $\mathrm{Al}_{\mathrm{x}} \mathrm{Cu}_{\mathrm{y}} \mathrm{Co}_{\mathrm{z}} \mathrm{Fe}_{2} \mathrm{O}_{4}$ (where $\mathrm{x}+\mathrm{y}+\mathrm{z}=1$ ) nanomaterials, which crystallise in a cubic spinel $\mathrm{AFe}_{2} \mathrm{O}_{4}$ structure are investigated systematically with a gradual substitution of $\mathrm{Al}$ by transition metals. The crystal structure information studied by X-ray diffraction (XRD) depicts the formation of single phase spinel structure, while electron-dispersive X-ray spectroscopy (EDX) reveals the stoichiometric relations of $\mathrm{Al}, \mathrm{Cu}$ and $\mathrm{Co}$.

Keywords: energy storage, supercapacitors, transition metals, spinel structure, nanostructured materials, redox reactions.
\end{abstract}

\section{Introduction}

Fossil fuels, supplying $80 \%$ of all energy consumed worldwide are facing rapid resource depletion and renewable energies are being sought to satisfy the growing energy demand $[1,2]$. However, the production of clean, renewable energy is only part of the energy puzzle faced by the planet. At the forefront of these are electrical energy storage techniques, such as batteries and supercapacitors. In order to meet the higher requirements of future electronic systems, the performance of energy storage devices must be increased by developing new materials and advancing the understanding of nanoscale electrochemical interfaces. Over the recent years, the supercapacitors technology has matured tremendously. As opposed to 
batteries, supercapacitors demonstrated high power density as well as high cycling capability. Whilst batteries are efficient in supplying constant energy at steady power levels, supercapacitors can provide high power during surges [3-6].

The large specific capacitance of electrochemical supercapacitors arises from double-layer capacitance (a non-Faradic process) and charge-transfer-reaction pseudocapacitance (which is a Faradic process). These two mechanisms can work separately or together, depending on the active materials (Aricò et al. [7]).

Herein, we report the synthesis of $\mathrm{Al}_{\mathrm{x}} \mathrm{Cu}_{\mathrm{y}} \mathrm{Co}_{\mathrm{z}} \mathrm{Fe}_{2} \mathrm{O}_{4}$ (where $\mathrm{x}+\mathrm{y}+\mathrm{z}=1$ ) nanocomposites using simple chemical methods. Symmetric supercapacitors were fabricated using metal oxide/ activated carbon nanocomposite electrode materials and their electrochemical performances were evaluated using a two-electrode configuration.

\section{Experimental}

\subsection{Synthesis of metal oxide}

The metal oxide nanomaterials were synthesised using the sol-gel method (Niederberger [8]). Metal nitrates were chosen since they dissolve easily. All the reagents (Sigma-Aldrich) in the experiment are considered to be of analytical grade and are used without further purification. Ultrapure water was obtained from a Millipore Milli-Q equipment. In order to obtain $\mathrm{Al}_{\mathrm{x}} \mathrm{Cu}_{\mathrm{y}} \mathrm{Co}_{\mathrm{z}} \mathrm{Fe}_{2} \mathrm{O}_{4}$ nanomaterials $(\mathrm{x}+\mathrm{y}+\mathrm{z}=1)$, appropriate amounts of $\mathrm{Al}\left(\mathrm{NO}_{3}\right)_{3} \cdot 9 \mathrm{H}_{2} \mathrm{O}, \mathrm{Cu}\left(\mathrm{NO}_{3}\right)_{2}, \mathrm{Co}$ $\left(\mathrm{NO}_{3}\right)_{2} \cdot 6 \mathrm{H}_{2} \mathrm{O}, \mathrm{Fe}\left(\mathrm{NO}_{3}\right)_{3} \cdot 9 \mathrm{H}_{2} \mathrm{O}$ were dispersed in $80 \mathrm{ml}$ of de-ionised water by ultrasonication with the addition of $20 \mathrm{ml}$ of iso-propyl alcohol. The mixture was sonicated for 5 minutes and citric acid was added which acts as a chelating agent and assists in the removal of nitrates (Yue et al. [9]). The mixture was slowly evaporated at $120^{\circ} \mathrm{C}$ for 12 hours under continuous magnetic stirring of $150 \mathrm{rpm}$. The resulting slurry was evaporated to dryness in a tubular furnace with temperature stages of $150^{\circ} \mathrm{C}, 350^{\circ} \mathrm{C}, 450^{\circ} \mathrm{C}$ and $600^{\circ} \mathrm{C}$.

\subsection{General characterisation of composites}

The nanocomposite materials were characterised by a powder X-ray diffraction system (XPERT-PRO XRD operated at $33 \mathrm{~mA}$ and $45 \mathrm{kV}$ with $\mathrm{CuK} \alpha$ radiation $(\lambda=1.54056 \AA)$ in the range of $20^{\circ}$ to $80^{\circ}$ with step size of $\left.0.03^{\circ}\right)$. The surface morphology and microstructure of the samples were investigated by scanning electron microscopy (model Quanta 400 FE-SEM). The elemental composition was identified using energy dispersive X-ray analysis (EDX). The BrunauerEmmett-Teller (BET) surface area of the samples were determined using a surface area and porosimetry system 'Micrometrics' (ASAP 2020) at $77 \mathrm{~K}$. Composition of the samples were analysed using thermogravimetric analysis (TGA Perkin Elmer) at $20^{\circ} \mathrm{C} / \mathrm{min}$ in static air. 


\subsection{Preparation of electrodes and electrochemical measurements}

Circular electrodes of $1.5 \mathrm{~cm}$ in diameter were prepared using synthesised metal oxides nanomaterial by the following procedure. The composite was mixed with carbon black (XL6) and a binding agent, polyvinylidene fluoride (PVDF) in the ratio of 7:2:1. An amount of $15 \%$ of carbon black by weight was found to enhance the conductivity of $\mathrm{Fe}_{3} \mathrm{O}_{4}$ nanomaterial significantly (Du et al. [10]). A carbon electrode was prepared in a similar procedure with activated carbon, carbon black and PVDF. The two electrodes were sandwiched in a supercapacitor test cell (ECC-std, EL-Cell GmbH) with a separator soaked in a $1 \mathrm{M} \mathrm{KOH}$ solution. The electrochemical properties of the supercapacitor electrodes were studied by symmetric assemblies of each material in a two-electrode configuration by cyclic voltammetry (CV) and galvanostatic charge-discharge tests using Arbin Instruments. The cell capacitance ( $C$ in $\mathrm{F}$ ) was calculated according to eqn (1) or from the charge-discharge curves according to eqn (2)

$$
C=\frac{i}{s}
$$

where ' $\mathrm{i}$ ' is the average cathodic current of the CV loop and's' is the scan (Khomenko et al. [11]),

$$
C=\frac{I}{(d V / d t)}
$$

where 'I' is the constant current for the charge-discharge $d V / d t$ is the slope of the discharge curve (Philip et al. [12]). The specific capacitance $\left(\mathrm{C}_{\mathrm{sp}}\right.$ in $\left.\mathrm{Fg}^{-1}\right)$ was then calculated as:

$$
C_{s p}=\frac{C}{m}
$$

where ' $\mathrm{m}$ ' is the mass of active material in the electrode.

\section{Results and discussion}

Aluminium, copper and cobalt-doped spinel ferrites were prepared by a conventional sol-gel processing method. SEM images of (a) $\mathrm{Al}_{0.2} \mathrm{Cu}_{0.4} \mathrm{Co}_{0.4} \mathrm{Fe}_{2} \mathrm{O}_{4}$, (b) $\mathrm{Al}_{0.4} \mathrm{Cu}_{0.3} \mathrm{Co}_{0.3} \mathrm{Fe}_{2} \mathrm{O}_{4}$, (c) $\mathrm{Al}_{0.6} \mathrm{Cu}_{0.2} \mathrm{Co}_{0.2} \mathrm{Fe}_{2} \mathrm{O}_{4}$ and (d) $\mathrm{Al}_{0.8} \mathrm{Cu}_{0.1} \mathrm{Co}_{0.1} \mathrm{Fe}_{2} \mathrm{O}_{4}$ with 2500X, 10000X and 80000X magnification respectively are shown in Figure 1. Cracks and in-built pores with diameters ranging from 0.2 to $4 \mu \mathrm{m}$ are observed in the nanomaterial. The increase in aluminium doping shows a decrease in the number of pores. These powders are polydisperse and show agglomeration due to magneto-dipole interactions between powders ( $\mathrm{NuLi}$ and Qin [13]). 
(a)
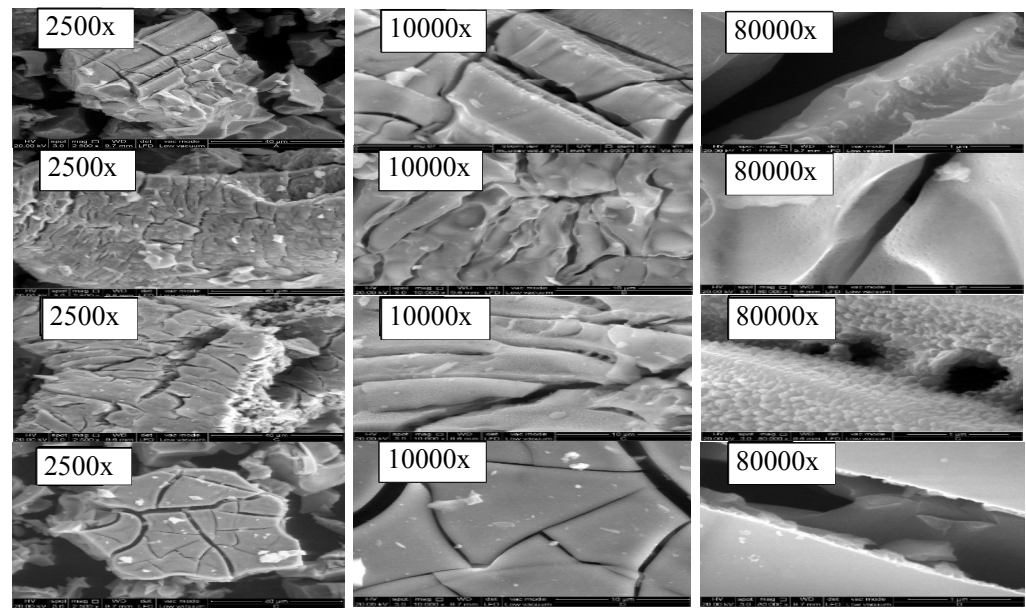

Figure 1: $\quad \mathrm{SEM}$ for (a) $\mathrm{Al}_{0.2} \mathrm{Cu}_{0.4} \mathrm{Co}_{0.4} \mathrm{Fe}_{2} \mathrm{O}_{4}$,

(b) $\mathrm{Al}_{0.4} \mathrm{Cu}_{0.3} \mathrm{Co}_{0.3} \mathrm{Fe}_{2} \mathrm{O}_{4}$, (c) $\mathrm{Al}_{0.6} \mathrm{Cu}_{0.2} \mathrm{Co}_{0.2} \mathrm{Fe}_{2} \mathrm{O}_{4}$ and (d) $\mathrm{Al}_{0.8} \mathrm{Cu}_{0.1} \mathrm{Co}_{0.1} \mathrm{Fe}_{2} \mathrm{O}_{4}$ with $2500 \mathrm{x}$, 10000x and 80000x magnification respectively.

EDX provides information about the chemical composition of a sample via the interactions between a source of X-rays excitation and the sample under investigation. As each element has a unique atomic structure, EDX enables the identification of elements via the unique set of peaks on the reflected X-ray spectrum. The EDX analysis of the compounds is shown in Figure 2 and the comparison between the actual and theoretical stoichiometry are summarised in Table 1.

The actual and theoretical stoichiometry was assumed to be the same for the oxygen atom in the compounds.

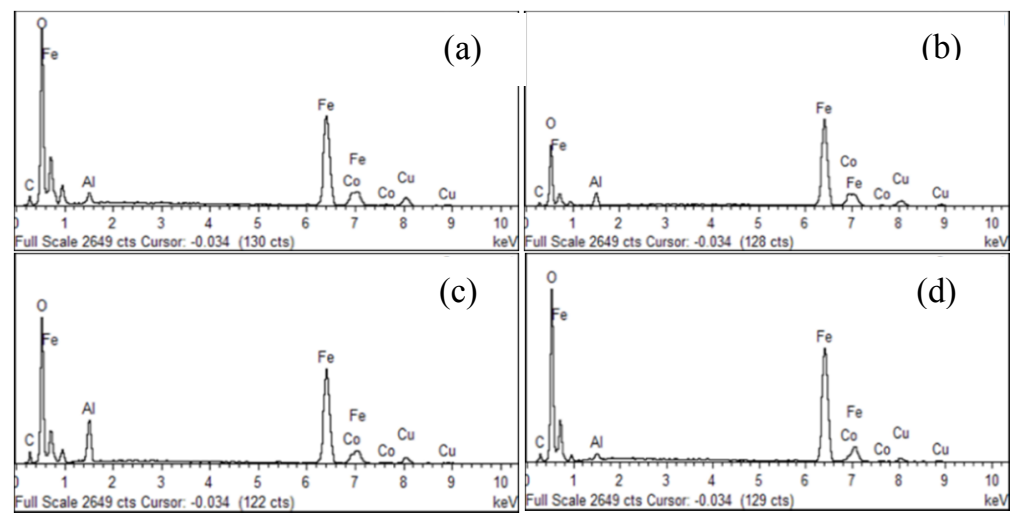

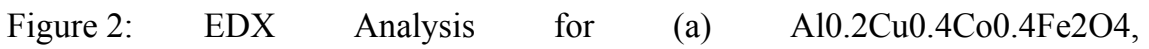

(b) $\mathrm{A} 10.4 \mathrm{Cu} 0.3 \mathrm{Co} 0.3 \mathrm{Fe} 2 \mathrm{O} 4$, (c) $\mathrm{A} 10.6 \mathrm{Cu} 0.3 \mathrm{Co} 0.3 \mathrm{Fe} 2 \mathrm{O} 4$ and

(d) $\mathrm{Al} 0.8 \mathrm{Cu} 0.1 \mathrm{Co} 0.1 \mathrm{Fe} 2 \mathrm{O} 4$. 
From Table 1, it can be observed that there are discrepancies between the theoretical and actual stoichiometries of the sample. At low percentages of aluminium doping $\left(\mathrm{Al}_{0.2} \mathrm{Cu}_{0.4} \mathrm{Co}_{0.4} \mathrm{Fe}_{2} \mathrm{O}_{4}\right.$ and $\left.\mathrm{Al}_{0.4} \mathrm{Cu}_{0.3} \mathrm{Co}_{0.3} \mathrm{Fe}_{2} \mathrm{O}_{4}\right)$, the actual stoichiometries are almost the same as the theoretical ones. The SEM micrographs (Figure 1) confirm that the morphology of the sample is stable. For high percentage of aluminium doping, $\left(\mathrm{Al}_{0.6} \mathrm{Cu}_{0.2} \mathrm{Co}_{0.2} \mathrm{Fe}_{2} \mathrm{O}_{4}\right.$ and $\left.\mathrm{Al}_{0.8} \mathrm{Cu}_{0.1} \mathrm{Co}_{0.1} \mathrm{Fe}_{2} \mathrm{O}_{4}\right)$, the actual stoichiometries do not match the theoretical one. This indicates that a too high percentage of aluminium in the sample, does not yield the expected compound. This could be because the structure is not stable at high levels of aluminium doping. Hence, the nanomaterial tends to stabilize with a lower aluminium percentage.

Table 1: Comparison between theoretical and actual stoichiometries.

\begin{tabular}{|c|c|c|c|c|}
\hline Compound & \multicolumn{2}{|c|}{ Theoretical stoichiometry } & \multicolumn{2}{|c|}{ Actual stoichiometry } \\
\hline \multirow[t]{5}{*}{$\mathrm{Al}_{0.2} \mathrm{Cu}_{0.4} \mathrm{Co}_{0.4} \mathrm{Fe}_{2} \mathrm{O}_{4}$} & $\mathrm{Al}$ & 0.2 & $\mathrm{Al}$ & 0.15 \\
\hline & $\mathrm{Cu}$ & 0.4 & $\mathrm{Cu}$ & 0.3 \\
\hline & Co & 0.4 & $\mathrm{Co}$ & 0.38 \\
\hline & $\mathrm{Fe}$ & 2 & $\mathrm{Fe}$ & 1.5 \\
\hline & $\mathrm{O}$ & 4 & $\mathrm{O}$ & 4 \\
\hline \multirow[t]{5}{*}{$\mathrm{Al}_{0.4} \mathrm{Cu}_{0.3} \mathrm{Co}_{0.3} \mathrm{Fe}_{2} \mathrm{O}_{4}$} & $\mathrm{Al}$ & 0.4 & $\mathrm{Al}$ & 0.28 \\
\hline & $\mathrm{Cu}$ & 0.3 & $\mathrm{Cu}$ & 0.23 \\
\hline & $\mathrm{Co}$ & 0.3 & Co & 0.29 \\
\hline & $\mathrm{Fe}$ & 2 & $\mathrm{Fe}$ & 1.4 \\
\hline & $\mathrm{O}$ & 4 & $\mathrm{O}$ & 4 \\
\hline \multirow[t]{5}{*}{$\mathrm{Al}_{0.6} \mathrm{Cu}_{0.2} \mathrm{Co}_{0.2} \mathrm{Fe}_{2} \mathrm{O}_{4}$} & $\mathrm{Al}$ & 0.6 & $\mathrm{Al}$ & 0.19 \\
\hline & $\mathrm{Cu}$ & 0.2 & $\mathrm{Cu}$ & 0.13 \\
\hline & Co & 0.2 & $\mathrm{Co}$ & 0.11 \\
\hline & $\mathrm{Fe}$ & 2 & $\mathrm{Fe}$ & 0.16 \\
\hline & $\mathrm{O}$ & 4 & $\mathrm{O}$ & 4 \\
\hline \multirow[t]{5}{*}{$\mathrm{Al}_{0.8} \mathrm{Cu}_{0.1} \mathrm{Co}_{0.1} \mathrm{Fe}_{2} \mathrm{O}_{4}$} & $\mathrm{Al}$ & 0.8 & $\mathrm{Al}$ & 0.35 \\
\hline & $\mathrm{Cu}$ & 0.1 & $\mathrm{Cu}$ & 0.04 \\
\hline & $\mathrm{Co}$ & 0.1 & Co & 0.04 \\
\hline & $\mathrm{Fe}$ & 2 & $\mathrm{Fe}$ & 1.25 \\
\hline & $\mathrm{O}$ & 4 & $\mathrm{O}$ & 4 \\
\hline
\end{tabular}

The XRD patterns of the four nano materials (Figure 3) show peaks from respective metal oxides. The main characteristic peak of the prepared samples occur at around $2 \theta=36^{\circ}$ which exists in typical spinel structure (JCPDS card No. 98-009-6221 and space group Fd3m) (Bao et al. [14]). No other phases have been detected. 
(a)

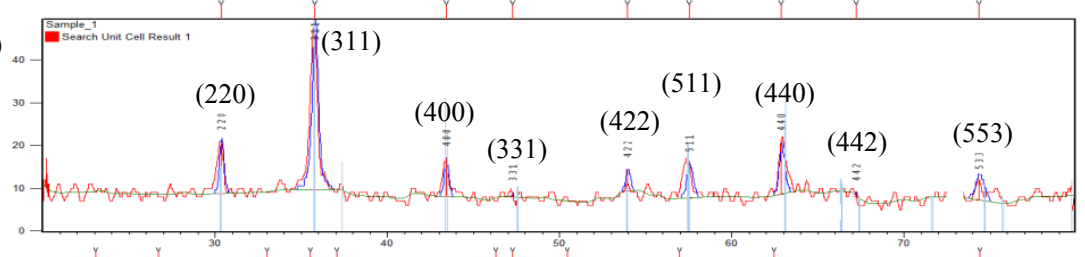

(b)

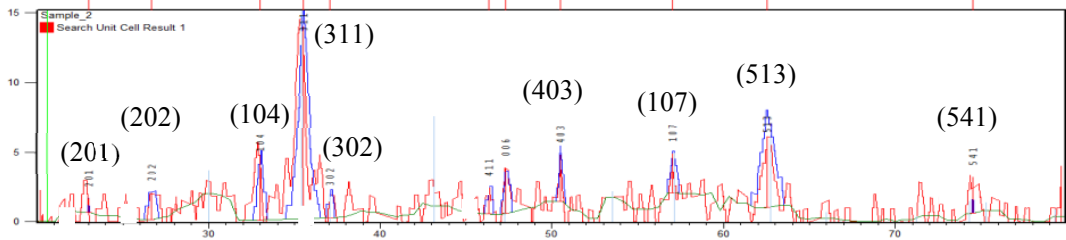

(c)

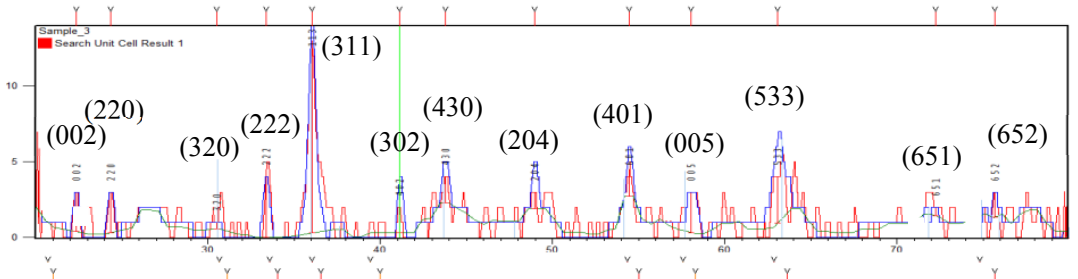

(d)

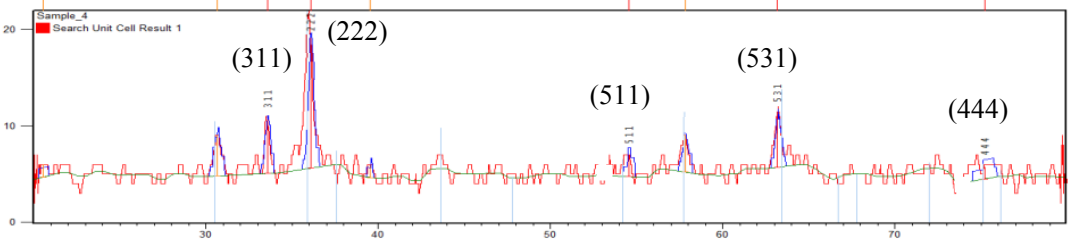

Figure 3: $\quad \mathrm{XRD}$ patterns (a) $\mathrm{Al}_{0.2} \mathrm{Cu}_{0.4} \mathrm{Co}_{0.4} \mathrm{Fe}_{2} \mathrm{O}_{4}$, (b) $\mathrm{Al}_{0.4} \mathrm{Cu}_{0.3} \mathrm{Co}_{0.3} \mathrm{Fe}_{2} \mathrm{O}_{4}$, (c) $\mathrm{Al}_{0.6} \mathrm{Cu}_{0.2} \mathrm{Co}_{0.2} \mathrm{Fe}_{2} \mathrm{O}_{4}$ and (d) $\mathrm{Al}_{0.8} \mathrm{Cu}_{0.1} \mathrm{Co}_{0.1} \mathrm{Fe}_{2} \mathrm{O}_{4}$ spinel ferrites.

The chemical composition of the metal oxide nanocomposites precursor are determined using thermogravimetric analysis (TGA). Figure 4 shows the typical TGA curve of $\mathrm{Al}_{0.2} \mathrm{Cu}_{0.4} \mathrm{Co}_{0.4} \mathrm{Fe}_{2} \mathrm{O}_{4}$. The other 3 nanomaterials demonstrate a similar trend. The major weight loss was observed between $150^{\circ} \mathrm{C}$ and $350^{\circ} \mathrm{C}$ and is attributed to the loss of nitrate contents in the sample. The sample weight stabilises after $600^{\circ} \mathrm{C}$ indicating that at the reaction temperature the dehydration is complete [15-17].

Nitrogen-adsorption and -desorption isotherms of the metal oxide nanomaterials are shown in Figure 5. Using these isotherms, the BET surface area values for $\mathrm{Al}_{0.2} \mathrm{Cu}_{0.4} \mathrm{Co}_{0.4} \mathrm{Fe}_{2} \mathrm{O}_{4}, \mathrm{Al}_{0.4} \mathrm{Cu}_{0.3} \mathrm{Co}_{0.3} \mathrm{Fe}_{2} \mathrm{O}_{4}, \mathrm{Al}_{0.6} \mathrm{Cu}_{0.2} \mathrm{Co}_{0.2} \mathrm{Fe}_{2} \mathrm{O}_{4}$ and $\mathrm{Al}_{0.8} \mathrm{Cu}_{0.1} \mathrm{Co}_{0.1} \mathrm{Fe}_{2} \mathrm{O}_{4}$ are calculated as $114.7,78.5,29.6$ and $48.6 \mathrm{~m}^{2} / \mathrm{g}$ respectively. The surface area of metal ferrites obtained in the present work is comparable with work reported by Ramankutty and Sugunan [18] where specific surface area of 94.6 and $187.9 \mathrm{~m}^{2} / \mathrm{g}$ with cobalt and copper ferrites respectively were obtained. Based on the density function theory model (DFT), pore volumes of 0.11 , $0.15,0.23$ and $0.09 \mathrm{~cm}^{3} \mathrm{~g}^{-1}$ are obtained for the $\mathrm{Al}_{0.2} \mathrm{Cu}_{0.4} \mathrm{Co}_{0.4} \mathrm{Fe}_{2} \mathrm{O}_{4}$, 
$\mathrm{Al}_{0.4} \mathrm{Cu}_{0.3} \mathrm{Co}_{0.3} \mathrm{Fe}_{2} \mathrm{O}_{4}, \mathrm{Al}_{0.6} \mathrm{Cu}_{0.2} \mathrm{Co}_{0.2} \mathrm{Fe}_{2} \mathrm{O}_{4}$ and $\mathrm{Al}_{0.8} \mathrm{Cu}_{0.1} \mathrm{Co}_{0.1} \mathrm{Fe}_{2} \mathrm{O}_{4}$ respectively. The apparent increase in pore volume is due to the high concentration of transition metal oxides in $\mathrm{Al}_{0.2} \mathrm{Cu}_{0.4} \mathrm{Co}_{0.4} \mathrm{Fe}_{2} \mathrm{O}_{4}, \quad \mathrm{Al}_{0.4} \mathrm{Cu}_{0.3} \mathrm{Co}_{0.3} \mathrm{Fe}_{2} \mathrm{O}_{4}$ and $\mathrm{Al}_{0.6} \mathrm{Cu}_{0.2} \mathrm{Co}_{0.2} \mathrm{Fe}_{2} \mathrm{O}_{4}$ (Arico et al. [19]).

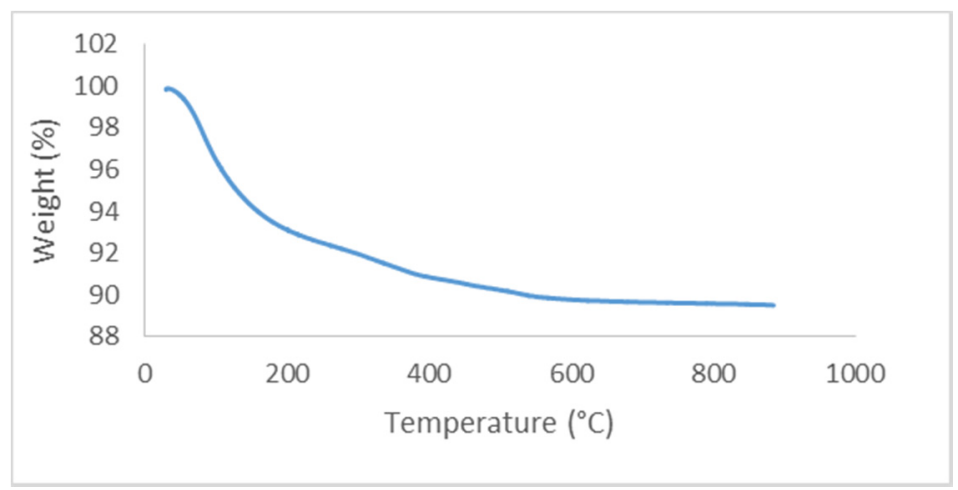

Figure 4: $\quad$ TGA Curve for $\mathrm{Al}_{0.2} \mathrm{Cu}_{0.4} \mathrm{Co}_{0.4} \mathrm{Fe}_{2} \mathrm{O}_{4}$.

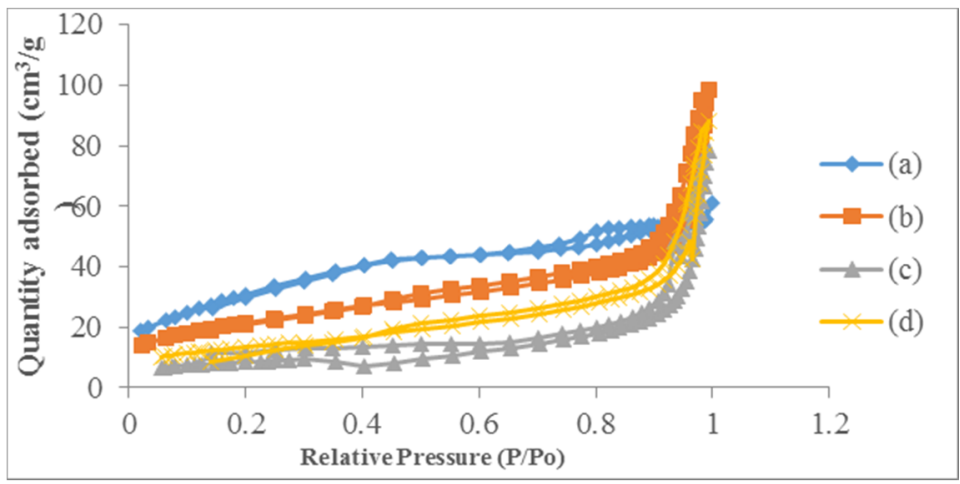

Figure 5: Nitrogen-adsorption and -desorption isotherms of (a) $\mathrm{A} 10.2 \mathrm{Cu} 0.4 \mathrm{Co} 0.4 \mathrm{Fe} 2 \mathrm{O} 4$, (b) $\mathrm{A} 10.4 \mathrm{Cu} 0.3 \mathrm{Co} 0.3 \mathrm{Fe} 2 \mathrm{O} 4$, (c) $\mathrm{A} 10.6 \mathrm{Cu} 0.2 \mathrm{Co} 0.2 \mathrm{Fe} 2 \mathrm{O} 4$ and (d) $\mathrm{Al} 0.8 \mathrm{Cu} 0.1 \mathrm{Co} 0.1 \mathrm{Fe} 2 \mathrm{O} 4$.

In the present study, $\mathrm{Al}_{\mathrm{x}} \mathrm{Cu}_{\mathrm{y}} \mathrm{Co}_{\mathrm{z}} \mathrm{Fe}_{2} \mathrm{O}_{4}$ (where $\mathrm{x}+\mathrm{y}+\mathrm{z}=1$ ) based supercapacitor devices demonstrates typical $\mathrm{CV}$ curves. A comparison of $\mathrm{CV}$ loops of the four nanomaterials at scan rates of 100, 50, 10 and $5 \mathrm{mV} / \mathrm{s}$ is shown in Figure 6(a). The curves show no peaks, indicating that the supercapacitor is charged and discharged at a pseudo-constant rate over the complete voltammetric cycle. At lower scan rates, an almost ideal capacitive behaviour is observed. As the scan rate increases, the deviation from rectangularity of the $\mathrm{CV}$ becomes obvious. A good kinetic reversibility is an important factor for ideal capacitor behaviour. It can also be seen that for the four nanomaterials, the redox current increases with increasing scan rate which indicates good rate ability [20-23]. 
Figure 6(b) shows the variation in specific capacitance as a function of scan rate. Tsay et al. [24] demonstrated that the specific capacitance decreases with increasing charging rate; similar to the result shown in Figure 6(b).The decrease in specific capacitance with increasing charging rate is due to the limited transfer of ions to the pores, leading to inaccessible pore portions of the electrode layer at high charging rates. A high specific capacitance of $875 \mathrm{~F} / \mathrm{g}$ was obtained with $\mathrm{Al}_{0.2} \mathrm{Cu}_{0.4} \mathrm{Co}_{0.4} \mathrm{Fe}_{2} \mathrm{O}_{4}$ which can be attributed to the high roughness and porous microstructure of the nanomaterial $[25,26]$.

(a)
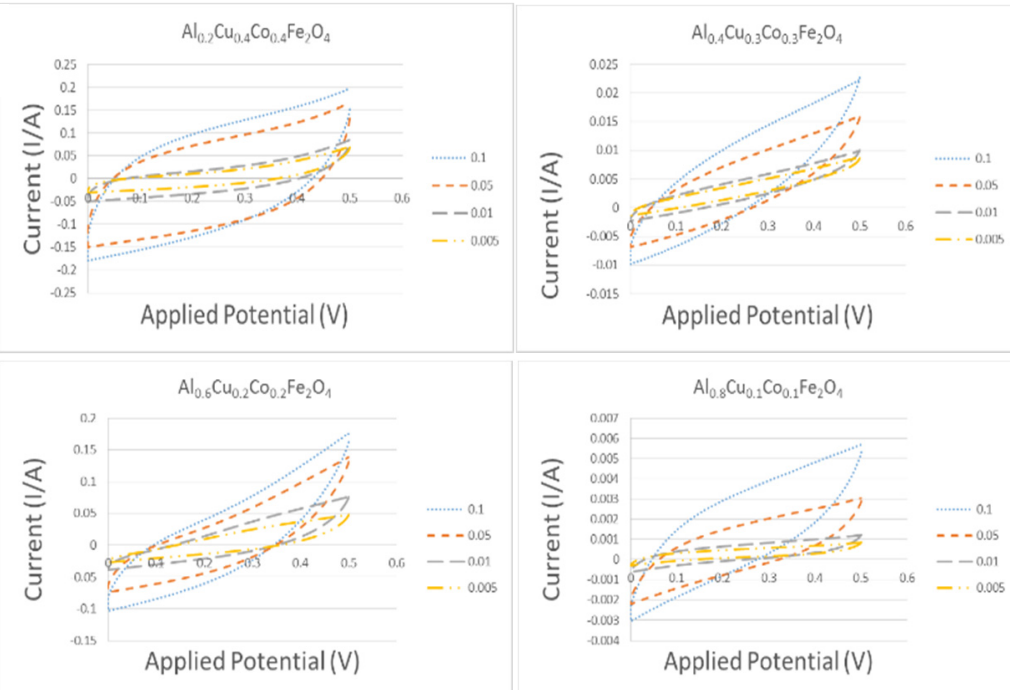

(b)

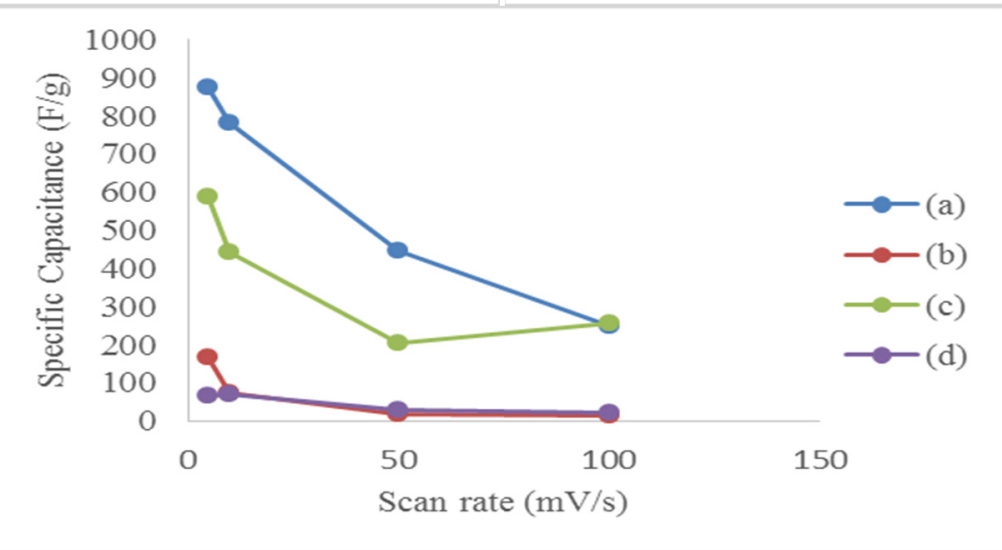

Figure 6: (a) Comparison of cylic voltammograms of $\mathrm{Al}_{0.2} \mathrm{Cu}_{0.4} \mathrm{Co}_{0.4} \mathrm{Fe}_{2} \mathrm{O}_{4}$, $\mathrm{Al}_{0.4} \mathrm{Cu}_{0.3} \mathrm{Co}_{0.3} \mathrm{Fe}_{2} \mathrm{O}_{4}, \mathrm{Al}_{0.6} \mathrm{Cu}_{0.2} \mathrm{Co}_{0.2} \mathrm{Fe}_{2} \mathrm{O}_{4}$ and $\mathrm{Al}_{0.8} \mathrm{Cu}_{0.1} \mathrm{Co}_{0.1} \mathrm{Fe}_{2} \mathrm{O}_{4}$ at scan rates of $100,50,10$ and $5 \mathrm{mV} / \mathrm{s}$ and (b) the specific capacitance change as a function of scan rate. 
The galvanostatic charge-discharge curves of symmetric supercapacitors based on functionalised $\mathrm{Al}_{\mathrm{x}} \mathrm{Cu}_{\mathrm{y}} \mathrm{Co}_{\mathrm{z}} \mathrm{Fe}_{2} \mathrm{O}_{4}$ (where $\mathrm{x}+\mathrm{y}+\mathrm{z}=1$ ) and activated carbon electrodes at a current density of $0.1 \mathrm{~A} / \mathrm{g}$ in the range of 0 and $+1 \mathrm{~V}$ are shown in Figure 7. Charge-discharge measurements are critical in the analysis and prediction of the active materials performance under practical operating conditions. It can be observed that the charge/discharge profiles of $\mathrm{Al}_{0.2} \mathrm{Cu}_{0.4} \mathrm{Co}_{0.4} \mathrm{Fe}_{2} \mathrm{O}_{4}, \quad \mathrm{Al}_{0.4} \mathrm{Cu}_{0.3} \mathrm{Co}_{0.3} \mathrm{Fe}_{2} \mathrm{O}_{4}, \quad$ and $\mathrm{Al}_{0.6} \mathrm{Cu}_{0.2} \mathrm{Co}_{0.2} \mathrm{Fe}_{2} \mathrm{O}_{4}$ exhibit isosceles, triangle-like shapes indicating a good reversibility [27, 28]. $\mathrm{Al}_{0.8} \mathrm{Cu}_{0.1} \mathrm{Co}_{0.1} \mathrm{Fe}_{2} \mathrm{O}_{4}$ takes a longer time to charge to the maximum voltage of $1 \mathrm{~V}$. $\mathrm{Al}_{0.4} \mathrm{Cu}_{0.3} \mathrm{Co}_{0.3} \mathrm{Fe}_{2} \mathrm{O}_{4}$ has a high charge-discharge capability because the structure of the nanocomposite is considered to be stable from the aluminium doping as well as possessing a high percentage of cobalt and copper. $\mathrm{Al}_{0.2} \mathrm{Cu}_{0.4} \mathrm{Co}_{0.4} \mathrm{Fe}_{2} \mathrm{O}_{4}$ and $\mathrm{Al}_{0.6} \mathrm{Cu}_{0.2} \mathrm{Co}_{0.2} \mathrm{Fe}_{2} \mathrm{O}_{4}$ demonstrate average charge and discharging time but not as fast as $\mathrm{Al}_{0.4} \mathrm{Cu}_{0.3} \mathrm{Co}_{0.3} \mathrm{Fe}_{2} \mathrm{O}_{4}$. This could be explained by the fact that there is a lower percentage of aluminium in $\mathrm{Al}_{0.2} \mathrm{Cu}_{0.4} \mathrm{Co}_{0.4} \mathrm{Fe}_{2} \mathrm{O}_{4}$ and a smaller percentage of transition elements in $\mathrm{Al}_{0.6} \mathrm{Cu}_{0.2} \mathrm{Co}_{0.2} \mathrm{Fe}_{2} \mathrm{O}_{4}$. As the percentage of transition elements in the compounds is decreased $\left(\mathrm{Al}_{0.8} \mathrm{Cu}_{0.1} \mathrm{Co}_{0.1} \mathrm{Fe}_{2} \mathrm{O}_{4}\right)$, the time taken for the supercapacitor to charge increases.

The maximum storage energy $(E)$ per unit mass for $\mathrm{Al}_{0.2} \mathrm{Cu}_{0.4} \mathrm{Co}_{0.4} \mathrm{Fe}_{2} \mathrm{O}_{4}$, $\mathrm{Al}_{0.4} \mathrm{Cu}_{0.3} \mathrm{Co}_{0.3} \mathrm{Fe}_{2} \mathrm{O}_{4}$, and $\mathrm{Al}_{0.6} \mathrm{Cu}_{0.2} \mathrm{Co}_{0.2} \mathrm{Fe}_{2} \mathrm{O}_{4}$ and $\mathrm{Al}_{0.8} \mathrm{Cu}_{0.1} \mathrm{Co}_{0.1} \mathrm{Fe}_{2} \mathrm{O}_{4}$ based symmetric supercapacitors are calculated as 1.1, 20, 20.1 and $70 \mathrm{Whkg}^{-1}$ respectively, using eqn 4 (Ye et al. [29]).

$$
E=\frac{1}{2} C_{s p} V_{i}^{2}
$$

where $C_{s p}$ is the specific capacitance and $V_{i}$ is the initial voltage $(1.0 \mathrm{~V})$ of the discharge curve.

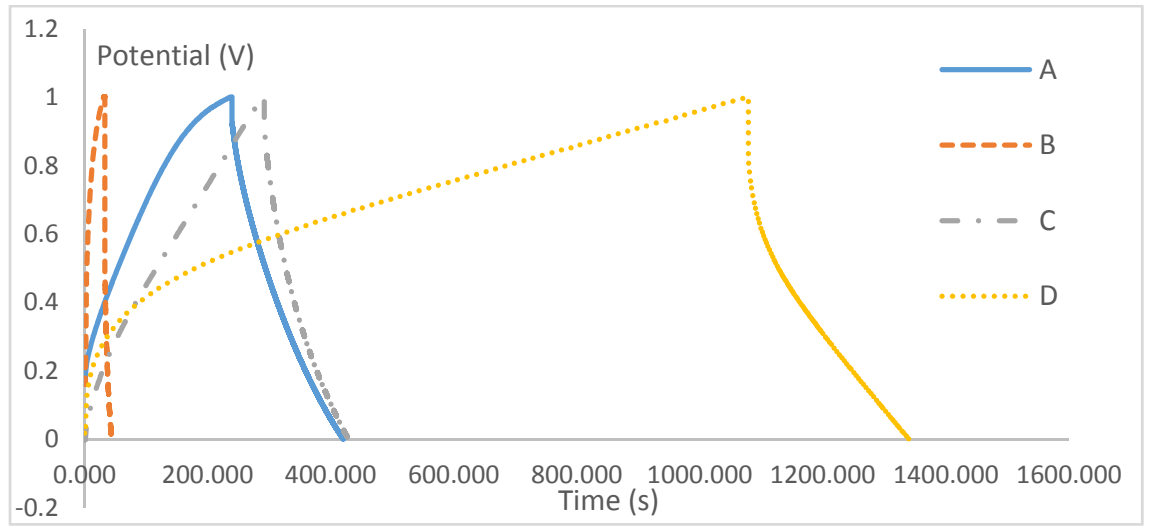

Figure 7: Galvanostatic charge-dischargecurves of (a) $\mathrm{Al}_{0.2} \mathrm{Cu}_{0.4} \mathrm{Co}_{0.4} \mathrm{Fe}_{2} \mathrm{O}_{4}$, (b) $\mathrm{Al}_{0.4} \mathrm{Cu}_{0.3} \mathrm{Co}_{0.3} \mathrm{Fe}_{2} \mathrm{O}_{4}, \quad$ (c) $\mathrm{Al}_{0.6} \mathrm{Cu}_{0.2} \mathrm{Co}_{0.2} \mathrm{Fe}_{2} \mathrm{O}_{4}$ and (d) $\mathrm{Al}_{0.8} \mathrm{Cu}_{0.1} \mathrm{Co}_{0.1} \mathrm{Fe}_{2} \mathrm{O}_{4}$ at a current density of $0.1 \mathrm{~A} / \mathrm{g}, 1 \mathrm{M} \mathrm{KOH}$ electrolyte. 


\section{Conclusions}

Nanocomposite pseudocapacitive materials possess immense potential as supercapacitor electrode material. Aluminium doping is required in order to stabilise the structure of the nanocomposite. The presence of transition elements enhances the performance of supercapacitors due to redox reactions. In this study, the electrochemical capacitive behaviour of transition metals with iron oxide and activated carbon nanocomposite electrode materials has been evaluated. $1 \mathrm{M} \mathrm{KOH}$ was used as electrolyte for the system. The study has demonstrated that the specific capacitance values (with respect to the composite mass) obtained for $\mathrm{Al}_{0.2} \mathrm{Cu}_{0.4} \mathrm{Co}_{0.4} \mathrm{Fe}_{2} \mathrm{O}_{4} \quad(875 \quad \mathrm{~F} / \mathrm{g})$ and $\mathrm{Al}_{0.6} \mathrm{Cu}_{0.2} \mathrm{Co}_{0.2} \mathrm{Fe}_{2} \mathrm{O}_{4} \quad(588.2 \mathrm{~F} / \mathrm{g})$ nanocomposites at a scan rate of $5 \mathrm{mV} / \mathrm{s}$ are the best ones reported out of all four nanomaterials tested. The pore size of the nanomaterials affects the capacitive behaviour of the electrodes. A large number of mesopores in the compound has been found to enhance capacitance. The capacitive performance of the electrodes is believed to originate from the synergestic effect of pseudocapacitance charge storage mechanism as well as the pore size of the core electrodes.

\section{References}

[1] Liserre, M., T. Sauter, and J.Y. Hung, Future Energy Systems: Integrating Renewable Energy Sources into the Smart Power Grid Through Industrial Electronics. Industrial Electronics Magazine, IEEE. 4(1): pp. 18-37, 2010.

[2] Johansson, T.B. and L. Burnham, Renewable Energy: Sources for Fuels and Electricity. 1993: Island Press.

[3] Li, B., et al., Review of recent progress in solid-state dye-sensitized solar cells. Solar Energy Materials and Solar Cells. 90(5): pp. 549-573, 2006.

[4] Hoel, M. and S. Kverndokk, Depletion of fossil fuels and the impacts of global warming. Resource and Energy Economics. 18(2): pp. 115-136, 1996.

[5] Conway, B.E., Electrochemical Supercapacitors: Scientific Fundamentals and Technological Applications. Kluwer, 1999.

[6] Eichenberg, D.J., Development and Testing of an Ultracapacitor Based Uninterruptible Power Supply (UPS) System. NASA/TM-2010-216780, http://gltrs.grc.nasa.gov, 2010.

[7] A. S. Aricò, P.B., Bruno Scrosati, Jean-Marie Tarasco \& Walter van Schalkwijk, Nanostructured materials for advanced energy conversion and storage devices. Nature Materials. 4: pp. 366-377, 2005.

[8] Niederberger, M., Nonaqueous Sol-Gel Routes to Metal Oxide Nanoparticles. Accounts of Chemical Research. 40(9): pp. 793-800, 2007.

[9] Yue, Z., et al., Synthesis of nanocrystalline NiCuZn ferrite powders by sol-gel auto-combustion method. Journal of Magnetism and Magnetic Materials. 208(1-2): pp. 55-60, 2000.

[10] Xi. Du; C. Wong; M. Chen; J. Wang, Y.J., Electrochemical performances of Nanoparticle Fe3O4/Activated Carbon Supercapacitor using $\mathrm{KOH}$ 
Electrolyte solution. Journal of Physical Chemistry C. 113: pp. 2643-2646, 2009.

[11] Khomenko, V., E. Frackowiak, and F. Béguin, Determination of the specific capacitance of conducting polymer/nanotubes composite electrodes using different cell configurations. Electrochimica Acta. 50(12): pp. 2499-2506, 2005.

[12] Philip, B., et al., Polyaniline / carbon nanotube composites: starting with phenylamino functionalized carbon nanotubes. Polymer Bulletin. 53(2): pp. 127-138, 2005.

[13] Y.-N. NuLi and Q.-Z. Qin, Nanocrystalline transition metal ferrite thin films prepared by an electrochemical route for Li-ion batteries. Journal of Power Sources. 142(1-2): pp. 292-297, 2005.

[14] Bao, N., et al., A Facile Thermolysis Route to Monodisperse Ferrite Nanocrystals. Journal of the American Chemical Society. 129(41): pp. 12374-12375, 2007.

[15] Schleich, D.M. and Y. Zhang, Preparation of some metal ferrite MFe2O4 thin films through a nonaqueous sol method. Materials Research Bulletin. 30(4): pp. 447-452, 1995.

[16] Rajić, N., et al., Formation of Nanocrystalline Transition-Metal Ferrites inside a Silica Matrix. Journal of the American Ceramic Society. 85(7): pp. 1719-1724, 2002.

[17] Ju, Y.-W., et al., Electrospun MnFe2O4 nanofibers: Preparation and morphology. Composites Science and Technology. 68(7-8): pp. 1704-1709, 2008.

[18] Ramankutty, C.G. and S. Sugunan, Surface properties and catalytic activity of ferrospinels of nickel, cobalt and copper, prepared by soft chemical methods. Applied Catalysis A: General. 218(1-2): pp. 39-51, 2001.

[19] Arico, A.S., et al., Nanostructured materials for advanced energy conversion and storage devices. Nat Mater. 4(5): pp. 366-377, 2005.

[20] Wang, Y.G., H.Q. Li, and Y.Y. Xia, Ordered Whiskerlike Polyaniline Grown on the Surface of Mesoporous Carbon and Its Electrochemical Capacitance Performance. Advanced Materials. 18(19): pp. 2619-2623, 2006.

[21] Zheng, J.P., Ruthenium Oxide-Carbon Composite Electrodes for Electrochemical Capacitors. Electrochemical and Solid-State Letters. 2(8): pp. 359-361, 1999.

[22] Kim, I.-H. and K.-B. Kim, Ruthenium Oxide Thin Film Electrodes for Supercapacitors. Electrochemical and Solid-State Letters. 4(5): pp. A62-A64, 2001.

[23] Jiang, J. and A. Kucernak, Electrochemical supercapacitor material based on manganese oxide: preparation and characterization. Electrochimica Acta. 47(15): pp. 2381-2386, 2002.

[24] Tsay, K.C., L. Zhang, and J. Zhang, Effects of electrode layer composition and thickness and electrolyte concentration on both specific capacitance and energy density of supercapacitor. Electrochimica Acta. 60: pp. 428-436, 2012. 
[25] Fan, L.-Z. and J. Maier, High-performance polypyrrole electrode materials for redox supercapacitors. Electrochemistry Communications. 8(6): pp. 937-940, 2006.

[26] Prasad, K.R. and N. Miura, Potentiodynamically deposited nanostructured manganese dioxide as electrode material for electrochemical redox supercapacitors. Journal of Power Sources. 135(1-2): pp. 354-360, 2004.

[27] Sivakumar, N., et al., Nanostructured $\mathrm{MgFe} 2 \mathrm{O} 4$ as anode materials for lithium-ion batteries. Journal of Alloys and Compounds. 509(25): pp. 7038-7041, 2011.

[28] Sen, P. and A. De, Electrochemical performances of poly $(3,4-$ ethylenedioxythiophene)-NiFe2O4 nanocomposite as electrode for supercapacitor. Electrochimica Acta. 55(16): pp. 4677-4684, 2010.

[29] Ye, C., Z.M. Lin, and S.Z. Hui, Electrochemical and Capacitance Properties of Rod-Shaped $\mathrm{MnO} 2$ for Supercapacitor. Journal of The Electrochemical Society. 152(6): pp. A1272-A1278, 2005. 